\title{
A TITULARIDADE SIMULTANEAMENTE INDIVIDUAL E TRANSINDIVIDUAL DOS DIREITOS SOCIAIS ANALISADA À LUZ DO EXEMPLO DO DIREITO À PROTEÇÃO E PROMOÇÃO DA SAÚDE*
}

\author{
INGO WOLFGANG SARLET ${ }^{* *}$
}

\begin{abstract}
RESUMO: O presente trabalho problematiza - com base na doutrina e na orientação jurisprudencial adotada pelo Supremo Tribunal Federal - a titularidade dos direitos fundamentais sociais, com destaque para o direito à saúde, discutindo a consistência dos argumentos que, por conta de uma dimensão exclusiva ou preponderantemente transindividual do direito à saúde, buscam - mediante recurso a diversificada argumentação - impedir ou limitar fortemente a utilização de demandas judiciais em caráter individual.

PALAVRAS-CHAVE: Direito à saúde; Titularidade; Direitos fundamentais; Supremo Tribunal Federal.
\end{abstract}

\begin{abstract}
The work at hand puts into question - based on the doctrine and the judicial orientation adopted by the Brazilian Federal Supreme Court - the entitlement of fundamental social rights, especially that of the right to health. It thus discusses the consistency of arguments which, due to an exclusively or predominantly trans-individual dimension of the right to health, aim at - with the use of a diverse reasoning - either preventing or harshly limiting the use of judicial complaints of an individual character. KEYWORDS: Right to health; Entitlement; Fundamental rights; Brazilian Supreme Federal Court.

SUMÁRIO: Notas Introdutórias; 1 . A titularidade dos direitos sociais no âmbito da Constituição Federal de 1988; 1.1. Dignidade da pessoa humana e o princípio da universalidade: Por um rol inclusivo em termos de titularidade dos direitos fundamentais; 1.2. A titularidade (individual e/ou transindividual?) dos direitos sociais como problema jurídico-constitucional; 2. A dupla dimensão individual e transindividual do direito à saúde e sua relevância no campo da exigibilidade dos direitos sociais como direitos subjetivos a prestações; Considerações Finais; Referências Bibliográficas.
\end{abstract}

\footnotetext{
Artigo recebido em 14.03.2010 e aprovado para publicação pelo Conselho Editorial em 30.03.2010.

* Agradecemos a Advogada da União, Mestre e Doutoranda (PUCRS) Mariana F. Figueiredo pela leitura atenta da primeira versão do texto e pelas diversas sugestões e críticas que em muito auxiliaram na revisão e no enriquecimento da versão ora publicada.

** Doutor e Pós-Doutor em Direito (Munique), Professor Titular da Faculdade de Direito e dos Programas de Mestrado e Doutorado em Direito e em Ciências Criminais da PUCRS. Juiz de Direito e Professor da Escola Superior da Magistratura (AJURIS)
} 
SUMMARY: Introductory Remarks; 1 . The Entitlement of social rights within the scope of the Brazilian 1988 Federal Constitution; 1.1. The human person's dignity and the universality principle: For an inclusive roll in terms of fundamental rights' entitlements; 1.2. The Entitlement (individual and/or trans-individual?) of social rights as a legal and constitutional issue; 2 . The dual individual and trans-individual dimension of the right to health and its relevance in the field of the enforceability of social rights as subjective entitlements to welfare services; Final remarks; Bibliographical references.

\section{NOTAS INTRODUTÓRIAS}

Dentre os diversos argumentos de relevo colacionados na esfera do debate em torno das possibilidades e limites no campo da problemática da exigibilidade, na condição de direitos subjetivos, dos assim chamados direitos fundamentais sociais, debate que no concernente ao direito à proteção e promoção da saúde assumiu uma posição de destaque no cenário nacional, situa-se, especialmente de algum tempo para cá, a objeção de que a concessão, pela via judicial, de prestações em caráter individual ou para determinados grupos, constitui via ilegítima de efetivação do direito à saúde. Na sustentação de tal linha argumentativa, advoga-se, por exemplo, que os direitos sociais são direitos de titularidade coletiva (transindividual ${ }^{1}$ ) e não permitem, por sua natureza, uma subjetivação individual, mormente para o efeito de serem deduzidos judicialmente ${ }^{2}$. Seguindo outro caminho, há os que preferem não questionar a titularidade propriamente dita dos direitos sociais, mas apontam para o fato de que a concessão individualizada de prestações por conta de processos individuais (ou mesmo para determinados grupos de litigantes) acarreta um impacto sobre o sistema público de saúde como tal, gerando - por várias razões - instabilidade e insegurança jurídicas, além de provocar "a desorganização da Administração Pública"3. Da mesma forma, existem ainda os que vislumbram na tutela judicial

${ }^{1}$ Para evitar alguma incompreensão, convém desde logo esclarecer que a expressão "Transindividual” (dimensão transindividual, direitos/interesses transindividuais), será aqui utilizada em termos genéricos, com o intuito de apontar para a existência de uma dimensão transindividual (coletiva e difusa) do direito e dever - a rigor, complexo de posições subjetivas e deveres - à proteção e promoção da saúde, no sentido de que a despeito de se tratar de um direito fundamental de titularidade individual (precisamente o ponto a ser sustentado neste trabalho) existe uma simultânea dimensão e mesmo titularidade coletiva e difusa. Assim, não será nosso objetivo analisar as diversas alternativas no que diz com a delimitação conceitual entre direitos individuais, individuais homogêneos, coletivos e difusos, não sendo também o caso de discutir a problemática envolvendo a distinção entre direitos e interesses. Sobre tais aspectos, v., dentre tantos, J.L. Bolzan de Morais, Do direito social aos interesses transindividuais, Porto Alegre: Livraria do Advogado Editora, 1996, bem como, já na perspectiva mais processual, T.A. Zavascki, Processo Coletivo. Tutela de Direitos Coletivos e Tutela Coletiva de Direitos, 4. ed., São Paulo: Revista dos Tribunais, 2009, especialmente p. 23-52.

2 Neste sentido, v., por todos, Luciano Timm, “Qual a maneira mais eficiente de prover direitos fundamentais: uma perspectiva de Direito e Economia”, in: Direitos Fundamentais, Orçamento e Reserva do Possível. I. W. Sarlet e L. B. Timm. (Orgs.). Porto Alegre: Livraria do Advogado, 2008. p. 55-68.

${ }^{3}$ Cf. a referência de L.R Barroso, "Da falta de Efetividade à Judicialização Excessiva: Direito à Saúde, Fornecimento Gratuito de Medicamentos e Parâmetros para a Atuação Judicial”, in: C. P. Souza Neto e D. Sarmento, Direitos Sociais. Fundamentos, Judicialização e Direitos Sociais em Espécie, Rio de Janeiro: Lumen Juris, 2008, p. 894, que, além disso, arrola outras críticas habitualmente endereçadas contra a judicialização da saúde, em especial no que diz com demandas individuais e casuísticas. Igualmente discorrendo sobre o ponto, v. C. P. Souza Neto, “A Justiciabilidade dos Direitos Sociais: Críticas e Parâmetros”, in: C. P. Souza Neto e D. Sarmento (Coord.), Direitos Sociais, op. cit., p. 528-29. 
individual uma violação do princípio da isonomia, argumentando, dentre outras razões que poderiam ser colacionadas, que tal sistemática acaba privilegiando apenas parcela da população, notadamente aquela que dispõe da informação e dos recursos suficientes para buscar o acesso ao sistema judiciário ${ }^{4}$. Vale mencionar, ainda, a reiterada alegação da violação (pelo menos potencial) do direito à saúde daqueles que, em função da alocação de recursos provocada pelas demandas judiciais individuais (ou que beneficiam determinados grupos), acabariam sendo prejudicados pela falta de recursos suficientes para o atendimento de suas necessidades, implicando verdadeiras decisões trágicas ${ }^{5}$. Ainda neste sentido, invoca-se a figura dos assim chamados free riders, ou seja, daqueles que aproveitam a via jurisdicional para assegurar benefícios que não teriam obtido pelo caminho administrativo habitual, ao qual acaba se submetendo a maior parte da população beneficiária do SUS, o que, por sua vez, também implica ofensa ao princípio isonômico ${ }^{6}$.

Tais argumentos apresentam aspectos comuns, e, de resto, não esgotam o rol de objeções que podem ser encontradas na doutrina e na jurisprudência. Por outro lado, não se busca apresentar um inventário completo, mas apenas destacar a relevância e diversidade da discussão a respeito da titularidade propriamente dita dos direitos sociais, em particular do direito à saúde. Além disso, pretende-se discutir a consistência de tal linha argumentativa, tanto no que se refere à negação da titularidade individual dos direitos sociais e do direito à saúde, quanto no que diz respeito à alegada impossibilidade de reconhecimento, em caráter individual, de direitos subjetivos a prestações em matéria de saúde. Tendo em conta a amplitude do tema, priorizar-se-á a vinculação do problema da titularidade dos direitos fundamentais sociais - com destaque para o caso do direito à saúde - com o princípio da dignidade da pessoa humana e do direito e garantia ao mínimo existencial, notadamente no que diz com a relevância de tais vetores para a superação (no todo ou em parte) das objeções acima colacionadas, bem como no concernente à orientação que vem sendo adotada, neste particular, pelo Supremo Tribunal Federal (STF), de tal sorte que, ressalvada eventual referência em caráter ilustrativo, não se trata de mapear e analisar a jurisprudência dos demais órgãos jurisdicionais brasileiros. Tal opção se justifica tanto em termos de limitação do tema quanto no que diz com uma preferência por uma abordagem de perfil qualitativo e não quantitativo.

No que diz com o caminho a ser percorrido, iniciar-se-á com uma breve análise do problema da titularidade dos direitos sociais em geral, para, num segundo momento, discutir os argumentos acima colacionados, buscando-se avaliar sua consistência e aptidão para impedir ou limitar a litigância individual no campo do direito à saúde, sempre à luz do exemplo do direito à saúde e da orientação jurisprudencial

\footnotetext{
${ }^{4}$ Cf., por todos, C. P. Souza Neto, “A Justiciabilidade dos Direitos Sociais: Críticas e Parâmetros”, op. cit., p. 533-34.

${ }^{5}$ Para esta perspectiva, v., por todos, o já clássico G. Amaral, Direito, Escasssez \& Escolha, 2. ed., Rio de Janeiro: Lumen Juris, 2010, especialmente p. 73 e ss.

${ }^{6}$ Cf., por todos, J. R. Lima Lopes, Direitos Sociais. Teoria e Prática. São Paulo: Método, 2006, especialmente p. 229, ao apresentar “a natureza do processo de direitos sociais” e destacar, ainda, a dificuldade do Poder Judiciário de lidar com questões de ordem distributiva.
} 
predominante no STF. Por derradeiro, antes de enfrentar o tema propriamente dito, conveniente destacar, na esteira do que oportunamente aponta Rogério Gesta Leal, que, a despeito do grande desenvolvimento do debate teórico (filosófico, político e jurídico) na seara dos direitos fundamentais no Brasil, o que - considerada a quantidade e qualidade da literatura disponível - se aplica também aos direitos sociais, cabe enfrentar o desafio posto pela necessidade de concretização de tais direitos, o que implica investimento urgente em fórmulas teóricas e práticas aptas a assegurar a efetividade das promessas constitucionais nesta seara ${ }^{7}$. É precisamente nesta perspectiva que se situa o presente texto, visto que busca discutir, à luz do problema da titularidade dos direitos fundamentais sociais, em que medida a opção por demandas individuais e/ou transindividuais opera como fator impeditivo ou facilitador da efetividade dos diretos sociais, com destaque para o direito à saúde.

\section{A TITULARIDADE DOS DIREITOS SOCIAIS NO ÂMBITO DA CONSTITUIÇÃO FEDERAL DE 1988}

\subsection{Dignidade da pessoa humana e o princípio da universalidade: por um rol inclusivo em termos de titularidade dos direitos fundamentais}

Em que pese a existência, no Brasil, de considerável doutrina utilizando o termo destinatário (no sentido de destinatário da proteção ou tutela do direito) como sinônima de titular de direitos fundamentais, ${ }^{8}$ é preciso enfatizar que a terminologia mais adequada e que, em termos gerais, corresponde à tendência dominante no cenário jurídico contemporâneo, é a de titular de direitos fundamentais. Titular do direito, notadamente na perspectiva da dimensão subjetiva dos direitos e garantias fundamentais, é quem figura como sujeito ativo da relação jurídico-subjetiva, de tal sorte que destinatário é a pessoa (física, jurídica ou mesmo ente despersonalizado) em face da qual o titular pode exigir o respeito, proteção ou promoção do seu direito.

Estabelecido o acordo semântico, mas ainda em caráter preliminar, assume-se, de outra parte, como correta a afirmação - amplamente difundida na literatura jurídico-constitucional contemporânea - de que a determinação da titularidade (independentemente da distinção entre titularidade e capacidade jurídica) de direitos fundamentais não pode ocorrer de modo prévio para os direitos fundamentais em geral, mas reclama identificação individualizada, à luz de cada norma de direito fundamental e das circunstâncias do caso concreto e de quem figura nos pólos da relação jurídica. ${ }^{9}$

\footnotetext{
${ }^{7}$ Cf. R. G. Leal. Condições e Possibilidades Eficaciais dos Direitos Fundamentais Sociais, Porto Alegre: Livraria do Advogado, 2009, p. 38.

${ }^{8}$ Por exemplo, J. A. da Silva, Curso de Direito Constitucional Positivo, 27. ed. São Paulo: Malheiros, 2006, p. 192; G. M. Bester, Direito Constitucional. Vol. I: Fundamentos Teóricos. Manole: Barueri, 2005, p. 569; W. de M. Agra, Curso de Direito Constitucional, Rio de Janeiro: Forense, 2006, p. 100. Já A. de Moraes, Direitos Humanos Fundamentais - Teoria Geral, 6. ed. São Paulo: Atlas, 2005, p. 72, passou a adotar, agora corretamente, a expressão “titulares” sob a rubrica “destinatários”, evidenciando a confusão de sentidos em parcela da doutrina brasileira.

${ }^{9}$ Cf. I. von Münch, Grundgesetz-Kommentar, vol. I, 5. ed., München: C.H, Beck, 2000, p. 24. Dentre nós, v. G. F. Mendes; I. M. Coelho; P. G. Gonet Branco. Curso de Direito Constitucional. 2. ed. São Paulo: Saraiva, 2008. p. 273-4; J. J. Gomes Canotilho. Direito Constitucional e Teoria da Constituição. 7. ed. Coimbra: Almedina, 2003. p. 424-5.
} 
No caso da CF de 1988, que serve de parâmetro para a presente analise, é preciso arrancar da constatação de que nela são se encontra, no que diz respeito à titularidade dos direitos fundamentais, referência expressa e direta ao assim chamado princípio da universalidade, visto que, a teor do disposto no artigo $5^{\circ}$, caput, da CF, são titulares dos direitos e garantias fundamentais os brasileiros e estrangeiros residentes no país, de tal sorte que, pelo menos no âmbito de uma exegese literal e restritiva, os estrangeiros não residentes não são titulares dos direitos constitucionalmente assegurados.

Todavia, doutrina e jurisprudência dominantes (embora alguma resistência isolada) acabaram por consagrar, também no direito brasileiro, o princípio da universalidade, que, embora sempre vinculado ao princípio da igualdade, com este não se confunde. Aliás, não é à toa que o constituinte, no mesmo dispositivo referido, enunciou que “todos são iguais perante a lei, sem distinção de qualquer natureza”, e, logo na seqüência, atribuiu a titularidade dos direitos fundamentais aos "brasileiros e estrangeiros residentes no País”. Assim, embora, diversamente do que estabeleceu, por exemplo, a Constituição Portuguesa de 1976 (artigo 12), no sentido de que "todos os cidadãos gozam dos direitos e estão sujeitos aos deveres consignados na Constituição”, uma interpretação sistemática não deixa margem a maiores dúvidas no tocante à recepção do princípio da universalidade no direito constitucional positivo brasileiro. ${ }^{10}$ De acordo com o princípio da universalidade, todas as pessoas, pelo fato de serem pessoas são titulares de direitos e deveres fundamentais, o que, por sua vez, não significa que não possa haver diferenças a serem consideradas, inclusive, em alguns casos, por força do próprio princípio da igualdade, além de exceções expressamente estabelecidas pela Constituição, como dá conta a diferenciação entre brasileiro nato e naturalizado, bem como algumas distinções relativas aos estrangeiros, entre outras.

Como bem leciona Gomes Canotilho, a universalidade será alargada ou restringida de acordo com a postura do legislador constituinte, sempre respeitando o núcleo essencial de direitos fundamentais, que é intangível por qualquer discricionariedade, núcleo que pode ser alargado pela atuação e concretização judicial dos direitos. ${ }^{11}$ Com efeito, a base antropológica dos direitos do homem concebe como sendo titulares de direitos inclusive os estrangeiros não residentes, assim como pessoas jurídicas de natureza pública e privada, como forma de concretização da justiça na condição de fundamento material, compatibilizando a universalidade com a igualdade no âmbito de uma apreciação tópica dos problemas enfrentados em face da necessária delimitação da titularidade. ${ }^{12}$ É preciso enfatizar, por outro lado, que o princípio da universalidade não é incompatível com o fato de que nem mesmo os brasileiros e os estrangeiros residentes no País são titulares de todos os direitos sem qualquer distinção, já que

\footnotetext{
${ }^{10}$ Sobre o tema, v. A. C. Nunes, A Titularidade dos Direitos Fundamentais na Constituição Federal de 1988, Porto Alegre: Livraria do Advogado, 2007.

${ }^{11}$ Sobre este aspecto, consultar a instigante doutrina de C. R. S. Castro, A Constituição Aberta e os Direitos Fundamentais - ensaios sobre um constitucionalismo pós-moderno e comunitário, Rio de Janeiro: Forense, 2005, p. 144 e ss., especialmente tendo em vista a questão da indivisibilidade dos direitos fundamentais do homem que merece tutela e proteção além fronteiras de Estado.

12 J. J. G. Canotilho, Direito Constitucional e Teoria da Constituição, 7. ed. Coimbra: Almedina, 2003, p. 418 e ss.
}

DIREITOS FUNDAMENTAIS E JUSTIÇA N' 10 - JAN./MAR. 2010 
direitos há que são atribuídos apenas a determinadas categorias de pessoas. Assim ocorre, por exemplo, com os direitos dos cônjuges, dos pais, dos filhos, dos trabalhadores, dos apenados, dos consumidores, tudo a demonstrar que há diversos fatores, permanentes ou vinculados a determinadas situações ou circunstâncias (como é o caso da situação familiar, da condição econômica, das condições físicas ou mentais, da idade, etc.) que determinam a definição de cada uma dessas categorias. Em suma, o que importa para efeitos de aplicação do princípio da universalidade, é que toda e qualquer pessoa que se encontre inserida em cada uma dessas categorias, seja em princípio titular dos respectivos direitos. ${ }^{13}$

A CF de 1988, no caput do seu art. $5^{\circ}$, reconhece como titular de direitos fundamentais, orientada pelo princípio da dignidade humana (inciso III do art. $1^{\circ}$ ) e pelos conexos princípios da isonomia e universalidade, toda e qualquer pessoa, seja ela brasileira ou estrangeira residente no País. Contudo - e a própria limitação quanto à residência no Brasil por parte dos estrangeiros já o indica - algumas distinções entre nacionais e estrangeiros devem ser observadas, designadamente no que diz com a cidadania e a nacionalidade, pois, como bem anotou Gilmar Mendes, “a nacionalidade configura vínculo político e pessoal que se estabelece entre o Estado e o indivíduo, fazendo com que este integre uma dada comunidade política, o que faz com que o Estado distinga o nacional do estrangeiro para diversos fins". ${ }^{14}$

Desde logo, é possível afirmar que a expressão brasileiros, consignada no art. $5^{\circ}$, caput, da CF, é de ser interpretada como abrangendo todas as pessoas que possuem a nacionalidade brasileira, independentemente da forma de aquisição da nacionalidade, ou seja, independentemente de serem brasileiros natos ou naturalizados, ressalvadas algumas exceções previstas na própria Constituição e que reservam aos brasileiros natos alguns direitos. De outra parte, o gozo da titularidade de direitos fundamentais por parte dos brasileiros evidentemente não depende da efetiva residência em território brasileiro, pois a titularidade depende exclusivamente do vínculo jurídico da nacionalidade, ao passo que para os estrangeiros a titularidade dos direitos assegurados na CF somente é reconhecida se estiverem residindo no Brasil, ${ }^{15}$ embora com isto não se esteja a delimitar - ainda - quais sejam tais direitos. De qualquer sorte, importa anotar, que há, além de direitos reservados apenas aos brasileiros naturalizados, direitos cuja titularidade é reservada aos estrangeiros, como é o caso do direito ao asilo político e a invocação da condição de refugiado e das prerrogativas que lhe são inerentes, direitos que, pela sua natureza, não são dos brasileiros ${ }^{16}$.

O fato de a CF ter feito expressa referência aos estrangeiros residentes, acabou colocando em pauta a discussão a respeito da extensão da titularidade de direitos

${ }^{13}$ Cf. J. Miranda e R. Medeiros. Constituição Portuguesa Anotada, Tomo I. Coimbra: Coimbra Editora, 2005. p. 112 e J. J. G. Canotilho, Direito Constitucional e Teoria da Constituição, op. cit., p. 328.

${ }^{14}$ G. F. Mendes, "Direito de Nacionalidade e Regime Jurídico do Estrangeiro”, in: Direitos Fundamentais \& Justiça, Revista do Programa de Pós-Graduação Mestrado e Doutorado da PUCRS, Porto Alegre: Ano 1, $n^{0} 1$, out./dez. 2007, p. 141-154.

${ }^{15}$ Cf. por todos, D. Dimoulis e L. Martins, Teoria Geral dos Direitos Fundamentais, São Paulo: RT, 2007, p. 82.

16 Sobre o tópico, v. o nosso A Eficácia dos Direitos Fundamentais. Uma teoria geral dos direitos fundamentais na perspectiva constitucional. 10. ed. Porto Alegre: Livraria do Advogado, 2009. p. 210-2. 
fundamentais aos estrangeiros não residentes no Brasil, bem como sobre a própria definição do que sejam estrangeiros residentes, para, sendo o caso, justificar eventual recusa da titularidade de direitos aos demais estrangeiros (não residentes). A despeito das severas críticas endereçadas - neste particular - ao constituinte de $1988^{17}$, tal distinção (entre estrangeiros residentes e não residentes), por ter sido expressamente estabelecida na CF, não pode ser pura e simplesmente desconsiderada, podendo, contudo, ser interpretada de modo mais ou menos restritivo, ou seja, ampliando a titularidade e, por conseguinte, a proteção constitucional dos direitos das pessoas, ou excluindo significativa parcela das pessoas da proteção de direitos fundamentais.

Uma primeira alternativa de interpretação mais extensiva guarda relação com a definição de estrangeiro residente e não residente, de tal sorte que, seja em homenagem aos princípios da dignidade da pessoa humana, isonomia e universalidade (fundamento aqui adotado), seja aplicando o princípio (próximo, mas não idêntico) do in dubio pro libertate, que impõe a interpretação mais favorável ao indivíduo em detrimento do Estado, como estrangeiros residentes são compreendidos todos os que, não sendo brasileiros natos ou naturalizados, se encontram, pelo menos temporariamente, no País, guardando, portanto, algum vínculo de certa duração. ${ }^{18}$ Este é o caso, por exemplo, do estrangeiro que trabalha no Brasil, resida com familiares ou mesmo aquele beneficiado com visto de duração superior a do turista ou de outra pessoa que apenas ingresse no País de forma eventual, por exemplo, para visitar amigos ou parentes, atividades profissionais de curta duração, entre outras.

Hipótese distinta é a da extensão da titularidade de direitos fundamentais a qualquer estrangeiro, ainda que não residente, mesmo nos casos em que tal não decorre diretamente de disposição constitucional expressa. Neste contexto, há que invocar o princípio da universalidade, que, fortemente ancorado no princípio da dignidade da pessoa humana, evidentemente não permite a exclusão generalizada de estrangeiros não residentes da titularidade de direitos, sendo correta a tese de que pelo menos todos os direitos diretamente fundados na dignidade da pessoa humana são extensivos aos estrangeiros. Também aqui assume relevo o que poderia ser chamado de função interpretativa do princípio da universalidade, que, na dúvida, estabelece uma presunção de que a titularidade de um direito fundamental é atribuída a todas as pessoas. ${ }^{19}$

A tese de que em face da ausência de disposição constitucional expressa os estrangeiros não residentes não poderiam ser titulares de direitos fundamentais, podendo apenas gozar dos direitos que lhes forem atribuídos por lei, visto a "consciente omissão” por parte do constituinte de 1988 apenas poderia ser corrigida por emenda constitucional, não pode prevalecer em face do inequívoco (ainda que implícito)

\footnotetext{
${ }^{17}$ V., dentre tantos, a particularmente enfática crítica de D. Dimoulis e L. Martins, Teoria Geral dos Direitos Fundamentais., op. cit., p. 85.

${ }^{18}$ Cf. também D. Dimoulis e L. Martins, ibidem, p. 85

${ }^{19}$ Cf. J. de M. Alexandrino, Direitos Fundamentais. Introdução Geral, Estoril: Principia Editora, 2007, p. 67. Entre nós, também adotando a tese da interpretação extensiva, especialmente com fundamento na dignidade da pessoa humana, v. G. Marmelstein, Curso de Direitos Fundamentais. São Paulo: Atlas Jurídico, 2008. p. 212 e ss., invocando uma série de precedentes jurisprudenciais adicionais.
} 
reconhecimento do princípio da universalidade, de acordo com a exegese imposta pelos princípios da dignidade da pessoa humana e da isonomia. Além disso, a recusa da titularidade de direitos fundamentais aos estrangeiros não residentes, que, salvo nas hipóteses expressamente estabelecidas pela Constituição, poderiam contar apenas com uma tutela legal (portanto, dependente do legislador infraconstitucional) viola frontalmente o disposto no art. $4^{\circ}$, inciso II, da CF, que, com relação à atuação do Brasil no plano das relações internacionais, estabelece que deverá ser assegurada a prevalência dos direitos humanos, posição que inclusive encontra respaldo em diversos julgados do STF. ${ }^{20}$ Também aqui deve valer a máxima de que na dúvida há de se assegurar a proteção dos direitos humanos e fundamentais a qualquer pessoa, ainda mais quando a sugerida "consciência da omissão” não corresponde visivelmente, em se procedendo a uma interpretação teleológica e sistemática, à resposta constitucionalmente adequada.

\subsection{A titularidade (individual e/ou transindividual?) dos direitos sociais como problema jurídico-constitucional}

No que diz com a titularidade dos direitos sociais (termo que aqui vai compreendido em sentido amplo, abarcando os direitos sociais, econômicos, culturais e ambientais no seu conjunto) não se trata, neste item, de retomar outras questões vinculadas ao tema da titularidade dos direitos fundamentais, notadamente no que diz com a eventual distinção entre brasileiros e estrangeiros (em especial os nãoresidentes no país), visto que quanto a este aspecto (no concernente ao fato de os estrangeiros serem, também, titulares de direitos) não se evidencia maior dissídio doutrinário quanto aos direitos sociais em particular. Em outras palavras, o que se está a sugerir, ainda que sem maior reflexão, é que as objeções no que diz com a atribuição da titularidade de direitos sociais a estrangeiros não-residentes situam-se, em geral - visto existirem exceções sujeitas à controvérsia ${ }^{21}-$, no mesmo plano dos argumentos habituais que refutam a tese da titularidade universal ou mesmo outros argumentos que objetivam justificar uma interpretação o mais inclusiva possível da titularidade dos direitos fundamentais.

${ }^{20}$ Paradigmáticas, neste sentido, diversas decisões em matéria de extradição, com destaque para o Processo de Extradição $n^{\circ}$ 633, STF, julgado em 28.08.1996, relator Min. Celso de Mello, onde precisamente restou consignado que a condição de estrangeiro não basta para reduzir a pessoa a um estado incompatível com sua dignidade, que lhe confere a titularidade de direitos inalienáveis, inclusive a garantia do devido processo legal. Neste mesmo julgamento, além de considerar aplicáveis ao estrangeiro as garantias da constituição brasileira, naquilo em que aplicáveis na espécie, houve invocação do argumento da necessária interpretação que assegure a prevalência dos direitos humanos, tal qual consignado no art. $4^{\circ}$, inciso II, da CF. Reforçando tal linha argumentativa, v. G. Marmelstein, Curso de Direitos Fundamentais, op. cit., p. 210, ao invocar, com oportunidade, o disposto no art. $1^{\circ}$ do Pacto de San José da Costa Rica, estabelecendo que titular dos direitos assegurados pela Convenção é todo o ser humano.

${ }^{21}$ Se já não se pode simplesmente ignorar a controvérsia em torno de ser o estrangeiro não residente titular do direito à saúde em termos gerais (embora a nossa posição favorável), os ânimos se exaltam quando se trata de discutir quais são as prestações que podem ser impostas ao Estado nesta seara, se apenas atendimento em caráter emergencial e provisório, ainda assim sujeito a limites. Em suma, em se tratando de estrangeiro, que, em princípio, deverá estar segurado (em sistema público e/ou privado) em seu país de origem, há que definir até onde vai o dever do Estado em alcançar prestações de saúde ao estrangeiro que se encontra em seu território. Embora a matéria já esteja pelo menos parcialmente regulada, cuida-se de tema inquietante, mas que aqui não será aprofundado. 
Por outro lado, considerando o amplo reconhecimento da titularidade de direitos fundamentais por parte de pessoas jurídicas e mesmo entes despersonalizados, não se haverá de adentrar tal aspecto, seja em face dos limites da abordagem, seja pelo fato de que o objetivo precípuo é o de discutir a legitimidade e o alcance das objeções relativas ao ajuizamento de demandas de caráter individual na esfera do direito à saúde. Com isto não se está afirmar - impende sublinhar - que a titularidade de direitos fundamentais por parte das pessoas jurídicas não tenha qualquer importância no campo dos direitos sociais (expressão ora utilizada em sentido genérico) em geral ou para o direito à saúde em particular, mas que se cuida de ponto que, para efeitos da discussão aqui proposta, não assume caráter central, razão pela qual se optou deixá-lo de lado, remetendo-se à literatura especializada ${ }^{22}$.

Apenas para reforçar os argumentos já deduzidos quanto ao ponto (v. item 2.1, supra), resulta evidente que a CF de 1988, em vários momentos, expressa ou implicitamente, atribuiu a titularidade de direitos sociais a toda e qualquer pessoa, independentemente de sua nacionalidade ou de seu vínculo de maior ou menor permanência com o Brasil, como ocorre, por exemplo, no caso do direito à saúde e da tutela do meio ambiente. Com efeito, de acordo com o disposto no art. 196, "a saúde é direito de todos e dever do Estado...”, ao passo que, na expressão do art. 225, "todos têm direito ao meio ambiente ecologicamente equilibrado...”. Por sua vez, dispõe o art. 203 que “a assistência social será prestada a quem dela necessitar...”, igualmente apontando para uma concepção inclusiva, neste caso, como dos direitos sociais básicos em geral (art. $6^{\circ}$ ), ainda mais quando em causa o assim chamado mínimo existencial e a garantia da própria vida e dignidade da pessoa humana, em estreita sintonia, portanto, com o já referido princípio da universalidade. De outra parte, como se pretende demonstrar logo a seguir, a utilização do termo “todos”, não constitui indicativo de que a titularidade será necessariamente coletiva (transindividual), ainda mais no sentido de uma exclusão da titularidade individual.

Aliás, é este precisamente um - embora não o único - adequado ponto de partida para a discussão que aqui se pretende empreender. Os direitos sociais (tanto na sua condição de direitos humanos, quanto como direitos fundamentais constitucionalmente assegurados) já pelo seu forte vínculo (pelo menos em boa parte dos casos) com a dignidade da pessoa humana e o correlato direito (e garantia) a um mínimo existencial ${ }^{23}$, surgiram e foram incorporados ao direito internacional dos

22 Sobre a titularidade de direitos fundamentais por parte das pessoas jurídicas, v., por todos, G. F. Mendes; I. M. Coelho; P. G. Gonet Branco. Curso de Direito Constitucional, op. cit., p. 271, embora se deva advertir para a circunstância de que não existe maior desenvolvimento da matéria no que diz com os direitos sociais da pessoa jurídica, tópico, de resto, altamente controverso, inclusive no que diz com a própria possibilidade de uma pessoa jurídica ser titular de um direito social típico (aqui poderiam ser referidas decisões judiciais, inclusive do STF, deferindo o benefício da assistência judiciária gratuita para sindicatos e entidades associativas). De qualquer modo, como já anunciado, cuida-se de tema a desafiar maior reflexão.

${ }^{23}$ Sobre a dignidade da pessoa humana e suas relações com os direitos fundamentais, v., por todos, o nosso Dignidade da Pessoa Humana e Direitos Fundamentais na Constituição Federal de 1988. 7. ed. Porto Alegre: Livraria do Advogado, 2009. A respeito do direito e garantia do mínimo existencial, v., na literatura brasileira, o nosso A Eficácia dos Direitos Fundamentais. op. cit., p. 402 e ss. bem como A. P. de Barcellos, A Eficácia Jurídica dos Princípios Constitucionais. O Princípio da Dignidade da Pessoa Humana. 
direitos humanos e ao direito constitucional dos direitos fundamentais como direitos referidos, em primeira linha, notadamente no que diz com a salvaguarda da dignidade da pessoa, à pessoa humana individualmente considerada ou a indivíduos integrando determinado grupos de pessoas em situação de desvantagem social, econômica e cultural.

Aliás, é preciso enfatizar que a convencional distinção estrita entre direitos individuais (terminologia habitualmente utilizada para designar os direitos civis e políticos) e direitos e deveres sociais, econômicos e culturais, atualmente ampliada pela inserção dos direitos e deveres em matéria ambiental, não encontra sua razão principal de ser na titularidade dos direitos, isto é, na condição de ser, ou não, a pessoa individualmente considerada um sujeito de direitos humanos e fundamentais, mas sim, mais propriamente na natureza e objeto do direito em cada caso. Em verdade, corresponde a uma tradição bastante arraigada, que os direitos individuais (civis e políticos) correspondem aos direitos de cunho negativo (defensivo), com destaque para os direitos de liberdade, que teriam por destinatário o poder público, implicando, por parte deste, deveres de abstenção, de não-intervenção na esfera da autonomia individual e dos bens fundamentais tutelados. Os direitos sociais, econômicos e culturais, por sua vez, igualmente conforme tal tradição, são (reitere-se, nesta ótica convencional e hoje pelo menos em parte superada) direitos cuja satisfação depende não mais de uma abstenção, mas sim, de uma atuação positiva, de um conjunto de prestações estatais, o que não afasta uma função defensiva de tais direitos, naquilo em que representam barreiras contra a intervenção por parte do Estado e de terceiros ${ }^{24}$. Aliás, consoante amplamente difundido na literatura sobre o tema ${ }^{25}$, foi justamente com base nesta diferenciação que os assim chamados direitos individuais (civis e políticos) acabaram sendo convencionalmente enquadrados numa primeira dimensão de direitos humanos e fundamentais, ao passo que os direitos sociais foram, em geral, referidos a uma segunda dimensão, marcada pela estreita relação com a igualdade material (direitos a prestações compensatórias de desigualdades fáticas). Já a assim designada terceira dimensão (não a dos direitos sociais prestacionais) acabou sendo vinculada à noção de solidariedade, de transindividualidade e mesmo de fraternidade, sem que se pretenda aqui discutir a correção de tais critérios.

Por mais que se saiba hoje que uma classificação dos direitos humanos e fundamentais assume função essencialmente didática e que todo os direitos sejam pautados por uma relação de complementaridade e conexão ${ }^{26}$, o que importa, para efeitos do presente item, é que nem a distinção entre direitos individuais e sociais,

Rio de Janeiro: Renovar, 2002; R. L. Torres. O Direito ao Mínimo Existencial, Rio de Janeiro: Renovar, 2008, e, por último, E. B. Neto, O Direito ao mínimo para uma existência digna, Porto Alegre: Livraria do Advogado, 2010.

${ }^{24}$ Sobre a dupla dimensão positiva e negativa também dos direitos sociais v., dentre tantos, o nosso Os Direitos Fundamentais Sociais na Constituição de 1988, in: I. W. Sarlet. (Org.). Direito Público em Tempos de Crise, p. 146 e ss; J. Miranda. Os Direitos Fundamentais - Sua Dimensão Individual e Social, in: $C D C C P$ n$^{\circ} 1$ (1992), p. 201; A. C. Wolkmer. Direitos Políticos, Cidadania e Teoria das Necessidades, in: $R I L \mathrm{n}^{\circ} 122$ ( 1994 ). p. 278 e ss.

${ }^{25}$ Cf., por todos, P. Bonavides, Curso de Direito Constitucional. 7. ed. São Paulo: Malheiros, 1998. p. 525 e ss.

${ }^{26}$ Para uma exposição do tema e simultaneamente uma perspectiva crítica, v. o nosso A Eficácia dos Direitos Fundamentais, op. cit. p. 45 e ss. 
nem mesmo a inserção de ambos os grupos de direitos em duas distintas dimensões ou gerações, foi em si pautada pelo critério da titularidade individual ou coletiva dos direitos civis e políticos em relação aos direitos sociais. Pelo contrário, direitos sociais (especialmente em se tratando dos direitos sociais básicos, como no caso da saúde, educação, previdência e assistência social e moradia, assim como no caso dos direitos dos trabalhadores a uma renda mínima, jornada de trabalho limitada, etc.) surgiram - como, de resto, os direitos humanos e fundamentais de um modo geral a partir de processos de reivindicação gestados no âmbito dos movimentos sociais na condição de direitos assegurados por força mesmo da dignidade de cada pessoa individualmente considerada, embora sempre da pessoa situada num contexto social e intersubjetivo. Aliás, mesmo a liberdade de associação sindical (apenas uma particular manifestação da liberdade de associação em sentido amplo) e o direito de greve (igualmente uma manifestação da liberdade de reunião, manifestação e expressão), não são tidos como direito exclusivamente coletivos, mas sim, direitos individuais de expressão coletiva (no sentido de uma interação entre a dimensão individual e a do grupo no qual se integra o individuo), visto que abrangem, no mais das vezes, a liberdade "negativa”, qual seja, a de não se associar ou de não participar de uma manifestação ou greve, embora a existência, como se sabe, de diferenciações importantes, a depender de cada ordem jurídica concretamente considerada. De outra parte, como há muito já o destacou Peter Häberle, todos os direitos fundamentais, em certa perspectiva, são direitos sociais, de modo especial em se considerando o vínculo entre a dignidade da pessoa humana e a democracia, visto que além de todos os direitos fundamentais apresentarem uma dimensão comunitária são também, em maior ou menor medida, dependentes de concretização por meio de prestações estatais ${ }^{27}$.

Em verdade, como bem demonstra José Ledur, as dimensões individual e coletiva (assim como difusa) coexistem, de tal sorte que a titularidade individual não resta afastada pelo fato do exercício do direito ocorrer na esfera coletiva, ${ }^{28}$ como ocorre, além dos casos já referidos, dentre outros que poderiam ser colacionados, no caso do mandado de segurança coletivo ${ }^{29}$. Aliás, embora não argumentando com base na generalidade dos direitos sociais, tal linha argumentativa foi desenvolvida também em julgado do Supremo Tribunal Federal, precisamente sustentando a coexistência de uma titularidade individual e coletiva do direito à saúde, ${ }^{30}$ sem prejuízo da existência de significativa jurisprudência reconhecendo - há muito tempo - um direito subjetivo individual a prestações em matéria de saúde. ${ }^{31}$

\footnotetext{
${ }^{27}$ Cf. P. Häberle, “Grundrechte im Leistungsstaat”, in: VVDStrL n. 30, 1972, p. 76.

${ }^{28}$ Cf. J. F. Ledur, Direitos Fundamentais Sociais. Efetivação no Âmbito da Democracia Participativa. Porto Alegre: Livraria do Advogado, 2009. p. 85-86.

${ }^{29}$ Neste contexto, oportuno referir a edição da Lei ${ }^{\circ}$ 12.016/2009, cujo art. 21 dispõe que o mandado de segurança coletivo destina-se à proteção de direitos coletivos (transindividuais) e de direitos individuais homogêneos; cf: http://www.planalto.gov.br/ccivil_03/_Ato2007-2010/2009/Lei/L12016.htm.

${ }^{30}$ Cf., em caráter ilustrativo, a decisão na suspensão de tutela antecipada 268-9, Rio Grande do Sul, Rel. Min. Gilmar Mendes, proferida em 22.10.2008, orientação recentemente confirmada em outros julgados, tais como se verifica no caso da decisão monocrática proferida pelo Presidente do STF, Min. Gilmar Mendes, na STA n 175, 18.09.2009.

${ }^{31}$ Cf., no âmbito do Supremo Tribunal Federal e dentre tantas, o assim considerado leading case do AgR-RE n 271.286-8/RS, Rel. Min. Celso de Mello, DJ 12.09.2000.
} 
Em verdade, causa mesmo espécie que de uns tempos para cá - como já demonstrado na parte introdutória do presente ensaio - haja quem busque refutar ainda que movido por boas intenções - a titularidade individual dos direitos sociais, como argumento de base para negar-lhes a condição de direitos subjetivos, aptos a serem deduzidos mediante demandas judiciais individuais. O curioso é que, consoante já adiantado, se trata de uma relativamente nova - e manifestamente equivocada! estratégia para impedir (o que é inaceitável sob todos os aspectos) ou eventualmente limitar (o que é possível e pode mesmo ser adequado) a assim chamada judicialização das políticas públicas e dos direitos sociais, restringindo o controle e intervenção judicial a demandas coletivas ou o controle estrito (concentrado e abstrato) de normas que veiculam políticas públicas ou concretizam deveres em matéria social, estratégia que - entre outros aspectos a serem desenvolvidos logo mais adiante - acaba por confundir a titularidade em si de um direito fundamental, ou seja, a condição da pessoa ser o sujeito de direitos, com eventual restrição do objeto do direito ou mesmo eventual restrição do acesso a alguma prestação por conta de uma condição econômica privilegiada ou outros critérios que aqui não se poderá aprofundar.

O que há de ser devidamente enfatizado nesta quadra, é a circunstância de que em geral os direitos humanos e fundamentais (civis, políticos e sociais), são sempre direitos referidos, em primeira linha, à pessoa individualmente considerada, e é a pessoa (cuja dignidade é pessoal, individual, embora socialmente vinculada e responsiva) o seu titular por excelência. Com efeito, como bem aponta Rodolfo Arango, parece óbvio e incontroverso que o titular por excelência dos direitos sociais seja o indivíduo, como demonstram os exemplos do direito à alimentação e do direito à saúde ${ }^{32}$. Possivelmente o exemplo mais contundente desta titularidade individual dos direitos sociais esteja atualmente associado ao assim designado direito (e garantia) ao mínimo existencial, por sua vez, fundado essencialmente na conjugação entre o direito à vida e o princípio da dignidade da pessoa humana, e que, precisamente por esta fundamentação, não pode ter sua titularidade individual afastada, por dissolvida numa dimensão coletiva. Nesta perspectiva situa-se o entendimento de Pérez Luño, para quem (recuperando a doutrina de George Gurvitch), embora os direitos sociais (como, aliás, se dá com os demais direitos humanos e fundamentais) sejam direitos da pessoa humana situada no seu entorno coletivo, isto não significa dizer que apenas possam ser exercidos no contexto coletivo (pela ação dos grupos ou coletividades), pois os direitos sociais encontram seu fundamento e sua função na proteção das pessoas no contexto de sua situação concreta na sociedade. ${ }^{33}$

Nesta perspectiva, aliás, o exemplo colacionado pelo autor na mesma passagem é elucidativo e guarda íntima relação com o argumento relacionado à dignidade da

${ }^{32}$ Cf. R. Arango, El concepto de derechos sociales fundamentales. Bogotá: LEGIS, 2005, em especial p. 59 e ss., destacando-se a afirmação do autor de que os titulares dos direitos sociais, na condição de direitos fundamentais, são exclusivamente indivíduos, não se tratando, nesta perspectiva, normas- objetivo, estabelecendo metas de ação, tarefas, para o poder público, além de não se tratar de direitos coletivos, no sentido de direitos cuja titularidade está atribuída a entes coletivos e coletividades.

${ }^{33}$ Cf. A. E. Pérez Luño, "La positividad de los derechos sociales en el marco constitucional”, in: Uma homenagem aos 20 anos da Constituição Brasileira, Florianópolis: Fundação Boiteux, 2008, p. 134-135. 
pessoa humana e ao mínimo existencial. Com efeito, o direito (humano e fundamental) de uma pessoa idosa ou de um incapaz à assistência tem por escopo imediato e, portanto, primordial (embora não exclusivo), a tutela do interesse individual na subsistência com dignidade, e não no interesse coletivo (ou social, se assim se preferir) na proteção e preservação dos idosos ou incapazes como membros de um grupo determinado, ainda que este interesse também assuma relevância e implique um conjunto de direitos e deveres. No caso do direito à saúde, a situação não diverge substancialmente, visto que a proteção da saúde não pode ser aplicada a todos sem qualquer tipo de distinção, o que não afasta, também neste caso, a possível e mesmo necessária convivência da perspectiva individual com a dimensão coletiva ${ }^{34}$, na esteira, aliás, do que já tem sido decidido pelo STF.

Embora a inviabilidade de aqui aprofundar o tópico, há que ter presente que, de modo particular onde em causa a tutela da vida, dos direitos de personalidade (que também dizem respeito à proteção e promoção da integridade e identidade física e psíquica da pessoa humana individualmente considerada) e das condições existenciais básicas, a observância das necessidades individuais e das peculiaridades do caso constitui condição precípua de respeito à dignidade da pessoa humana, que, a despeito da sua dimensão comunitária (a noção do indivíduo socialmente responsável e solidário), diz com a pessoa concreta, considerada na sua individualidade ${ }^{35}$. Que o conteúdo do mínimo existencial implica sua necessária contextualização, em virtude da sua relação com o ambiente social, econômico, cultural e mesmo natural (condições climáticas, por exemplo ${ }^{36}$ ) constitui mais uma razão para que não se possa dissolver o mínimo existencial (o que se aplica a todos os direitos sociais na sua relação com a garantia das condições materiais para uma existência digna) numa dimensão coletiva (comunitária) afastando a sua inequívoca titularidade individual, por mais que, reitere-se, a dimensão individual conviva (e também por esta é limitada) com uma perspectiva social e comunitária, de perfil transindividual.

Convém sublinhar que a noção de mínimo existencial - por mais que se possa discutir sobre sua fundamentação e conteúdo - guarda relação com a idéia de uma proteção da liberdade e da autonomia individual, visto que não se pode propriamente falar de uma autonomia coletiva. Dando conta disso, colaciona-se recentíssima decisão do Tribunal Constitucional Federal da Alemanha, que, ao reafirmar a existência de uma garantia do mínimo existencial fundada (também e essencialmente) na dignidade

\footnotetext{
${ }^{34}$ Sobre a dupla dimensão individual e coletiva do direito à saúde, v., amparada em jurisprudência constitucional, S. Juan, “L’objectif à valeur constitutionnelle du droit à la protection de la santé: droit individuel ou collectif?”, in: Revue du Droit Public et de la Science Politique en France et à L'ètranger nº 2, 2006, p. 442 e ss.

${ }^{35}$ A respeito do direito e garantia do mínimo existencial, v., entre outros, especialmente as monografias dedicadas ao tema da lavra de R. L. Torres, O Direito ao Mínimo Existencial. Rio de Janeiro: Renovar, 2009, e, por último, E. B. Neto, O Direito ao Mínimo para uma Existência Digna, Porto Alegre: Livraria do Advogado, 2010.

${ }^{36}$ Cf., entre outros, M. F. Figueiredo, Direito Fundamental à Saúde. Parâmetros para sua eficácia e efetividade, Porto Alegre: Livraria do Advogado, 2007, p. 291 (bem lembrando a necessidade de uma análise in concreto quando da determinação do conteúdo do mínimo existencial); Por último, também R. G. Leal, Condições e Possibilidades Eficaciais dos Direitos Fundamentais Sociais, op. cit., p. 92-93, bem explora tal perspectiva.
} 
da pessoa humana, bem adverte que se trata justamente do dever do Estado (e do correspondente direito do indivíduo) de assegurar a cada pessoa necessitada e carente do auxílio estatal as condições materiais indispensáveis para a sua existência física, além de propiciar um mínimo de participação (de cada indivíduo!) na vida social, cultural e política ${ }^{37}$.

Neste contexto, calha referir a afirmação de José Felipe Ledur, lembrando que no caso dos direitos sociais, embora em causa esteja a preocupação com o indivíduo como pessoa, assume relevo a condição da pessoa na sua relação com a comunidade, ao passo que nos direitos coletivos, o que sobressai é o conceito de grupo social ou entidade, sendo a coletividade em si que assume a posição de titular, isto é, de sujeito do direito fundamental. ${ }^{38}$ Na mesma perspectiva, situa-se o entendimento de Gerardo Pisarello, que, reconhecendo uma dimensão tanto individual quanto coletiva dos direitos sociais, igualmente refuta a tese dos direitos sociais compreendidos como direitos de dimensão exclusivamente coletiva, recordando que tanto direitos sociais, quanto direitos civis e políticos protegem bens jurídicos cuja incidência é simultaneamente individualizada e coletiva, como ocorre, no caso dos direitos sociais, com o direito à saúde, o direito à habitação e o direito à proteção ambiental, onde a afetação do direito pode produzir danos individuais e/ou transindividuais. Da mesma forma, no caso dos direitos civis e políticos, verifica-se uma maior ou menor dimensão coletiva, visto que tais direitos encerram também faculdades de associação para o exercício e tutela das liberdades. ${ }^{39}$

Para além de tais aspectos, verifica-se, como igualmente lembra Pérez Luño, que a titularidade dos direitos sociais não pode ser atribuída exclusivamente a grupos ou entes coletivos, já que a função dos direitos sociais corresponde também a assegurar cada pessoa individualmente considerada como desenvolvendo sua existência concreta mediante a integração em determinados grupos, mas com os quais pode situar-se em relação de oposição, designadamente quando presente um conflito de interesses. ${ }^{40}$ Sem prejuízo desta faceta, que corretamente aponta para a necessidade de uma distinção entre o indivíduo e o ente (entes) coletivos com os quais interage, e por mais que a tutela coletiva seja uma forma de assegurar a proteção da pessoa na sua individualidade (aliás, é a segurança e, portanto, proteção, que constitui um dos motivos da associação humana), importa agregar que mesmo no âmbito da tutela dos direitos difusos, a perspectiva individual não resulta completamente escamoteada, como, de resto, demonstra a possibilidade de execução individual da sentença obtida em ação coletiva e mesmo a possibilidade de cada pessoa deduzir em juízo eventual pretensão fundada em dano que possui natureza difusa, como é o caso dos danos pessoais (por exemplo, afetando a saúde) provocados por impacto ambiental ${ }^{41}$.

${ }^{37}$ Cf. BVerfG, 1 BvL I/09, 09.02.2010. disponível em http://www.bverfg.de/entscheidungen/Is20100209.

${ }^{38}$ Cf. J. F. Ledur, Direitos Fundamentais Sociais, op. cit., p. 87.

${ }^{39}$ Cf. G. Pisarello, Los derechos sociales y sus garantías, Madrid: Trotta, 2007, p. 72 e ss.

${ }^{40}$ Cf. A. E. Pérez Luño, "La positividad de los derechos sociales en el marco constitucional", in: Uma homenagem aos 20 anos da Constituição brasileira, op. cit., p. 149.

${ }^{41}$ Por certo que o autor não desconhece as discussões atualmente travadas no âmbito da doutrina processual, especialmente em decorrência da tramitação do Projeto de Lei n ${ }^{\circ}$ 5.139/2009, com destaque para a problemática da compatibilização entre as ações individuais e o "novo processo coletivo", sobretudo no que respeita à coisa julgada, debate que, todavia, foge aos limites deste estudo. 
Precisamente no que concerne a uma dimensão processual e embora tal perspectiva aqui não possa ser mais explorada, digno de nota a oportuna argumentação deduzida por Mariana Figueiredo, que, amparada nas lições de Gomes Canotilho, afirma a necessidade de se garantir, no âmbito de um Estado de Direito, uma proteção jurídico-judiciária individual sem lacunas, proteção esta que não poderia ser afastada no caso dos direitos sociais, notadamente quando evidenciada sua titularidade individual ${ }^{42}$.

Assim, na esteira do até agora exposto, há que insistir na tese que os direitos sociais não são sociais pelo fato de serem, em primeira linha (ou exclusivamente) direitos coletivos, no sentido de sua titularidade ser eminentemente coletiva. Os direitos sociais assim foram e têm sido designados por outra razão, mesmo no âmbito da superada distinção entre direitos individuais e direitos sociais, visto que tal distinção não repousa na titularidade coletiva dos direitos sociais, mas na natureza e objeto dos direitos, como, aliás, já frisado. Os direitos sociais, ou foram como tal nominados por serem direitos a prestações do Estado na consecução da justiça social, mediante a compensação de desigualdades fáticas e garantia do acesso a determinados bens e serviços por parte de parcelas da população socialmente vulneráveis, ou, como é o caso dos direitos dos trabalhadores (que incluem uma série de direitos típicos de liberdade e de igualdade, no sentido de proibições de discriminação), quando a qualificação de tais direitos como sendo também direitos sociais está diretamente vinculada à garantia de tutela de uma determinada classe social no âmbito de relações no mais das vezes marcadas por níveis de manifesta assimetria - e desequilíbrio - de poder econômico e social. Ainda que não estejamos aqui a esgotar - e nem é esta a pretensão - as justificativas para a designação ainda hoje praticada (embora não isenta de críticas, dada a substancial equivalência entre os diversos direitos fundamentais) - dos direitos sociais, o que importa é que se tenha presente que o fator distintivo não é em si a sua titularidade coletiva, em contraposição aos direitos civis e políticos, que seriam de titularidade individual.

Outra explicação para a atribuição de titularidade coletiva aos direitos sociais (acompanhada da negação da titularidade individual, pelo menos no campo dos direitos sociais mais básicos, como saúde, moradia e educação, por exemplo) pode estar vinculada à confusão entre a figura das políticas públicas e dos direitos sociais como direitos fundamentais. Neste contexto importa, ainda que em caráter sumário, insistir na distinção entre tais categorias. Com efeito, políticas públicas não se confundem com os direitos fundamentais, designadamente como direitos subjetivos (individuais e/ou coletivos e difusos) que são veiculados e tutelados ou promovidos por meio de políticas públicas, o que não afasta a possibilidade de um direito a que o Estado atue mediante políticas públicas, precisamente como forma de assegurar a efetividade de direitos fundamentais. Assim, além do controle da política pública como tal, que evidentemente resulta também na tutela de direitos, cuida-se de algo distinto quando se busca, muitas vezes já com base em determinada política pública (como bem revela o caso da legislação que obriga o poder público ao fornecimento de medicamentos)

${ }^{42}$ Cf. M.F. Figueiredo, “Apontamentos acerca do objeto do direito à saúde: para além do dever de prestação de medicamentos e tratamentos”, trabalho de conclusão de disciplina apresentado em dezembro de 2009 no âmbito do Doutorado em Direito da PUCRS, p. 07. 
obrigar o Estado a efetivamente assegurar a prestação ao indivíduo ou conjunto de indivíduos que deixou de ser atendido.

A tese segundo a qual os direitos sociais são direitos humanos e fundamentais referidos à pessoa individual, não deve ser compreendida, para espancar qualquer dúvida, como afastando uma dimensão transindividual (coletiva e difusa) dos direitos sociais, como se verifica no caso da conexão entre a proteção da saúde e a proteção do ambiente, ou mesmo no caso de políticas de saúde voltadas à prevenção e combate a doenças endêmicas, dentre tantos exemplos que poderiam ser colacionados apenas na esfera do direito à saúde. Também o direito ao trabalho, como direito social ancorado no art. $6^{\circ}$, da CF, fornece outro bom exemplo para demonstrar a conexão (mas não equivalência) entre uma dimensão individual e coletiva, visto que se refere tanto à garantia de condições de acesso a um trabalho digno para cada pessoa individualmente considerada e na sua proteção no âmbito das relações de trabalho (papel desempenhado pelos direitos dos trabalhadores dos artigos $7^{\circ}$ e seguintes da CF), mas apresenta uma face transindividual inequívoca, como fundamento da obrigação estatal de promover políticas que resultem na criação de vagas no mercado de trabalho. ${ }^{43}$

2. A DUPLA DIMENSÃO INDIVIDUAL E TRANSINDIVIDUAL DO DIREITO À SAÚDE E SUA RELEVÂNCIA NO CAMPO DA EXIGIBILIDADE DOS DIREITOS SOCIAIS COMO DIREITOS SUBJETIVOS A PRESTAÇÕES

Uma vez exposta a problemática da titularidade dos direitos fundamentais sociais e do direito à saúde e assumindo-se como correta a tese da simultaneidade de uma titularidade individual e transindividual (coletiva e mesmo difusa, a depender das circunstâncias) há que retomar as objeções expostas na parte introdutória, submetendo-as a uma análise crítica, ainda que inevitavelmente sumária e incompleta, fiéis, contudo, à proposta da presente abordagem, de contribuir para a discussão do problema, que, a depender da postura adotada pelos operadores do Direito, notadamente Juízes e Tribunais (mas também pelos integrantes das funções essenciais à Justiça, como é o caso do Ministério Público e da Defensoria Pública), poderá alcançar profunda repercussão prática, bastando apontar para a existência de decisões que, por conta de uma suposta titularidade coletiva, refutam demandas que buscam prestações individuais, mormente quando tais prestações não foram previstas na normativa vigente. Por outro lado, é possível perceber sem maior esforço que parte das objeções, embora por vezes venham acompanhadas de referências em prol de uma prevalente dimensão coletiva (transindividual), guardam relação mais próxima com outros argumentos, como é o caso do princípio isonômico, que, a despeito da eventual procedência parcial das razões colacionadas no sentido de obstaculizar ou limitar a litigância individual, não revela necessariamente uma incompatibilidade com a titularidade individual, mas sim, diz respeito ao impacto sobre outros direitos fundamentais causado pelas ações de caráter individual.

Quanto ao primeiro argumento colacionado, de acordo com o qual os direitos sociais são sempre direitos de titularidade coletiva (no sentido de serem direitos transindividuais) e que não permitem, por sua natureza, uma subjetivação individual,

${ }^{43}$ Cf., em especial, J. F. Ledur, Direitos Fundamentais Sociais, op. cit., p. 87. 
mormente para o efeito de serem deduzidos judicialmente, remete-se aos desenvolvimentos precedentes, onde tal questão foi objeto de detida análise, resultando na constatação, de resto suportada pela jurisprudência atualmente dominante no STF, de que a titularidade dos direitos sociais e do direito à saúde em particular é tanto individual quanto coletiva e mesmo difusa, não se podendo, pelo menos não de forma generalizada, afastar uma litigância individual com base nesta linha argumentativa.

Com relação aos que preferem não questionar a titularidade propriamente dita dos direitos sociais, mas apontam para o fato de que a concessão individualizada de prestações por conta de processos individuais (ou mesmo para determinados grupos de litigantes) acarreta um impacto sobre o sistema público de saúde como tal, gerando por várias razões - instabilidade e insegurança jurídicas, assim como ofensa ao princípio da isonomia, inclusive em função da violação do direito à saúde de terceiros, é preciso formular resposta mais detida.

Em primeiro lugar, importa sublinhar que o argumento de acordo com o qual a concessão judicial de prestações sociais a determinados indivíduos por vezes acarreta efeitos danosos e mesmo perversos em termos de justiça distributiva, além de estimular o fenômeno dos assim chamados "free-riders" "44 (predadores ou caronas) há de ser pelo menos relativizada. Com efeito, há que ter em conta que o respeito ao princípio da isonomia não pode servir de argumento para eventual violação da dignidade concreta de cada indivíduo, ainda mais quando o impacto negativo em relação a terceiros (não beneficiados pela tutela individual ou não-integrantes do grupo beneficiado), consistente, na maior parte das vezes e segundo a argumentação habitualmente deduzida, na possível inexistência de recursos para atendimento de outras demandas, na maior parte dos casos não é objeto de demonstração plausível. Além disso, o próprio sistema permite, com ressalvas é verdade, a realocação de recursos e mesmo dotações suplementares, de tal sorte que a tutela judicial em favor de alguns não resulta necessariamente na ausência de proteção para outros. De qualquer modo, para além da aplicação, também nesta esfera, da tese - que já encontra respaldo na jurisprudência do STF - de que é do poder público o ônus da prova no que diz com a falta efetiva (e justificada) de recursos para o atendimento de outras demandas ${ }^{45}$, persiste o problema (ético e jurídico) de saber até que ponto uma possível (dificilmente se poderá comprovar a certeza da afirmação) afetação de interesses de terceiros pode obstar o atendimento de necessidades prementes de pessoas cuja vida e dignidade

\footnotetext{
${ }^{44}$ Cf., por todos, J. R. L. Lopes, Direitos Sociais. Teoria e Prática, op. cit., p. 237.

${ }^{45}$ Aqui se aplica argumentação similar a que tem sido proposta no que diz respeito à invocação, pelo Poder Público, da objeção da reserva do possível, que, segundo importante doutrina, demanda demonstração plausível pelo Estado. Neste sentido, v. entre outros e mais recentemente, D. Sarmento "A proteção judicial dos direitos sociais: alguns parâmetros ético-jurídicos”, in: Direitos Sociais, op. cit., p. 572; C. P. Souza Neto, “A justiciabilidade dos direitos sociais: críticas e parâmetros”, in: Direitos Sociais, op. cit., p. 545 e ss.; P. Caliendo, Direito Tributário e Análise Econômica do Direito. Uma Visão Crítica. São Paulo: Elsevier, 2008. p. 204. No âmbito da jurisprudência, destaca-se, por último, decisão do Supremo Tribunal Federal referindo que cabe ao órgão estatal a prova da efetiva lesão ao erário público, aspecto que, embora não tenha sido o principal, contribuiu para o resultado do julgamento em prol da concessão do medicamento em demanda individual (Suspensão de Tutela Antecipada n ${ }^{\circ}$ 268-9, RS, Rel. Min. Gilmar Mendes, julgado em 22.10.2008).
} 
estão sob ameaça concreta e urgente. Daí resulta que tal linha argumentativa exige diálogo com outros argumentos, como é o caso da delimitação do objeto do direito à saúde (no sentido de quais as prestações que efetivamente devem ser alcançadas pelo Estado ao particular) bem como da discussão em torno da aplicação do princípio da subsidiariedade, de acordo com o qual o acesso ao sistema público de saúde deve ser reservado a quem não tem condições de manter um adequado plano de saúde privado e de assegurar com seus próprios recursos (ou de terceiros que tenham um dever de sustento) as prestações necessárias à salvaguarda de uma vida digna.

De outra parte, resulta no mínimo curioso o argumento de que a falta de isonomia quanto ao acesso à justiça, seja no que diz respeito à distribuição desigual em termos de assistência judiciária (incluindo a estruturação dos órgãos da Defensoria Pública, que, em virtude de limitações materiais, sequer está devidamente implantada em muitos lugares), seja no que diz respeito ao nível de informação do cidadão no que diz com seus direitos, acaba gerando uma espécie de casta de privilegiados, que, em detrimento de expressivos segmentos da população, utilizam a via judicial para obtenção de prestações sociais.

Nesta perspectiva, situa-se também a alegação dos que, mediante a demonstração de que boa parte dos autores de demandas pleiteando prestações na área da saúde não são patrocinados pela Defensoria Pública ou órgãos de assistência judiciária gratuita, afirmam que a tutela jurisdicional tem beneficiado a parcela mais privilegiada da população, portanto, a classe média e mesmo alta ${ }^{46}$. Embora não se possa (e nem se queira) negar a existência de distorções mais ou menos graves em termos de acesso à justiça, tal qual já referido, também é certo que justamente em função da falta de estruturação adequada do sistema de assistência judiciária e de assistência jurídica em sentido mais amplo - distorção por conta da qual até mesmo pessoas que, em tese, integram a "clientela" da defensoria pública não dispõe do acesso a tal recurso - não se pode falar em criação de uma distorção pelo simples fato de que pessoas com recursos suficientes para não serem selecionadas para atendimento pela Defensoria Pública ou órgãos similares tenham os seus direitos reconhecidos pelo Poder Judiciário. Bastaria aqui lembrar - com base em exemplo extraído da prática decisória do STF (medicação custando cerca de $\mathrm{R} \$ 52.000,00$ mensais ${ }^{47}$ ) - da circunstância de que precisamente na seara da saúde, existem prestações tão dispendiosas que mesmo pessoas de alto padrão aquisitivo não as podem custear pessoalmente, isto sem falar no fato de que nem sempre (especialmente no caso dos medicamentos) se cuida de prestações cobertas pelos planos privados de saúde.

Por outro lado, sabe-se que boa parte das pessoas (possivelmente a ampla maioria) acaba sendo atendida, com maior ou menor regularidade e maior ou menor qualidade

\footnotetext{
${ }^{46}$ Cf., por exemplo, sustenta V. A. da Silva, "O Judiciário e as políticas públicas: entre transformação social e obstáculo à realização dos direitos sociais”, in: C. P. Souza Neto e D. Sarmento (Coord.), Direitos Sociais, op. cit., p. 594 e ss.

${ }^{47}$ No caso da STA n ${ }^{\circ}$ 175, apreciada pelo Presidente do STF, Ministro Gilmar Mendes (DJE 25.09.2009), estava em causa fornecimento de medicação para uma pessoa (portanto, demanda individual), representada pelo Ministério Público Federal, tendo sido feita a prova de que nem a beneficiária e nem sua família tinham condições de financiar, por conta própria, a aquisição regular do medicamento.
} 
pelo sistema público de saúde, visto que não fosse assim, o número de demandas nesta seara alcançaria seguramente cifras em muito superiores. É certo que apenas quem necessita (e eventuais exceções, ainda que se trate de milhares de casos, não podem de justificativa para, por si só, bloquear o acesso à via judicial) busca o sistema judiciário para satisfação das duas necessidades. Os litigantes individuais (e coletivos) não constituem um bando de mal-intencionados egoístas disposto a saquear, em benefício próprio e com o auxílio do Ministério Público, da Defensoria Pública e do Poder Judiciário, os cofres públicos, o que, embora não seja como tal formulado em algumas falas, acaba, por vezes, pelo menos sendo sugerido sutilmente. Que eventuais excessos hão de ser contidos e critérios mais racionais e isonômicos desenvolvidos, constitui precisamente uma das preocupações que move o presente texto.

O fato é que a supressão pura e simples da tutela judicial individual (e mesmo coletiva, quando se trata de atender determinados grupos de pessoas) poderá gerar uma dupla violação do princípio isonômico. Com efeito, num primeiro plano, verifica-se que o Estado, ainda que investido (como o é, no mais das vezes) de boa fé, viola o dever de assegurar o acesso igualitário e universal estabelecido no artigo 196, da CF/88, que preceitua que a saúde é direito de todos e dever do Estado, garantido mediante políticas públicas que visem, entre outros, o acesso universal e igualitário a serviços para sua promoção, proteção e recuperação, ao excluir um grupo maior ou menor de indivíduos do acesso a determinadas prestações. Assim, a negativa de que quem (mesmo em caráter individual) não foi atendido não poderá obter a tutela jurisdicional, implica não apenas negar a possibilidade de efetivação do direito à saúde (com as conseqüências daí advindas em termos de violação - no plano jurídico e fático - de tal direito) quanto acaba por criar um segundo nível de “discriminação”, impedindo que tal indivíduo busque, por meio do Poder Judiciário, a correção da desigualdade. Com outras palavras, o cidadão é duplamente "punido”: a) por não ter recursos e necessitar do sistema de saúde pública que não o atende mesmo no que diz com prestações já previstas em lei; b) por não poder litigar para corrigir tal estado de coisas; Aliás, é precisamente por tal razão que, notadamente quando se trata de prestações já disponibilizadas pelo sistema de saúde, e, portanto, reguladas em caráter jurídico-normativo, se fala em direitos derivados a prestações, que, ao fim e ao cabo, são direitos de igual acesso às prestações já disponibilizadas na esfera das políticas públicas ${ }^{48}$. Que o afastamento ou mesmo uma forte limitação das demandas individuais, como de certa forma já anunciado, poderá representar uma violação também do direito-garantia de acesso à justiça (inafastabilidade do controle judicial) resulta evidente, não sendo o caso, todavia, de aqui avançar com tal linha argumentativa.

Por outro lado, é preciso guardar coerência com a tese de que por força da aplicabilidade imediata das normas de direitos fundamentais e da necessária preservação da supremacia da normativa constitucional, ao legislador e administrador (tal como ao Juiz) não se pode, especialmente em matéria de direitos fundamentais, assegurar ao legislador e ainda mais ao administrador uma margem de ação plena, absolutamente

${ }^{48}$ Sobre os assim chamados direitos derivados a prestações, v., por todos, J. J. Gomes Canotilho. Direito Constitucional e Teoria da Constituição, op. cit., p. 478-9. 
imune ao controle com base na constituição, permitindo, por exemplo, por omissão (deliberada, ou não) a exclusão de medicamentos ou outras prestações indispensáveis à própria vida da pessoa, além da necessária salvaguarda em relação a bens e serviços que possam dar conta das peculiaridades de casos individuais, já que as necessidades de cada pessoa (e mesmo alternativas de tratamento) podem variar fortemente de caso a caso, e a padronização pode resultar em inevitável exclusão de tratamento da doença em algumas situações. Com efeito, há que assegurar margem para o reconhecimento de direitos originários a prestações, portanto, não apenas direitos a prestações já definidas e disponibilizadas pelas políticas públicas praticadas, ainda que se possa discutir a respeito de quais os limites postos pela ordem jurídico-constitucional (bem como por outros fatores de cunho ético, econômico, etc.) em relação ao acesso a prestações ainda não reguladas em lei ${ }^{49}$.

Como já frisado, o que satisfaz o mínimo existencial guarda relação com necessidades físicas e psíquicas que, embora comuns às pessoas em geral, não podem levar a uma padronização excludente, pois o que o direito à saúde assegura mesmo no campo dos assim designados direitos derivados a prestações (!!!), não é necessariamente o direito ao atendimento limitado a determinado medicamento ou procedimento previamente eleito por essa mesma política, mas sim, o direito ao tratamento para a doença, tese que acabou sendo adotada pelo Superior Tribunal de Justiça na esfera dos planos de saúde ${ }^{50}$. Apenas com o intuito de reforçar a argumentação, vale citar decisão do Tribunal Constitucional Federal da Alemanha, que - nesta mesma linha de entendimento - afirmou que a ausência de previsão de determinado tratamento pelos protocolos oficiais e mesmo se cuidando, em regra, de tratamento reconhecido como ineficiente, a demonstração, no caso concreto, de que tal tratamento, ainda que alternativo, levou a uma melhora da condição de vida do paciente, não pode, por si só, afastar o direito a ter tal prestação financiada pelo seguro público de saúde, insistindo o Tribunal que é o acurado exame pelas instâncias ordinárias da Jurisdição que deverá levar, ao fim e ao cabo, a uma procedência ou improcedência do pleito formulado pelo cidadão, ainda que em caráter individual ${ }^{51}$.

Que a existência de distorções não pode ser completamente evitada e constitui um preço (relativamente baixo e controlável) a pagar, visto que a exclusão do acesso individual ou em grupo, notadamente quando se cuida de prestações de caráter existencial, acarreta disfunções e injustiças ainda maiores, deve servir de estímulo para ajustes necessários e possíveis. O aperfeiçoamento da via administrativa (no que diz respeito à clareza, simplicidade e acesso às informações, à desburocratização, à tempestividade, entre outros aspectos) constitui certamente o melhor caminho para tanto e se insere, num plano mais amplo, na noção de boa governança que também e acima de tudo deve imperar na esfera dos serviços públicos essenciais à garantia de uma vida digna, o que, por sua vez, implica ampliação e aperfeiçoamento dos

\footnotetext{
${ }^{49}$ A respeito da distinção entre direitos derivados e originários a prestações e os argumentos favoráveis e contrários ao reconhecimento de direitos subjetivos originários, v., por todos, o nosso A Eficácia dos Direitos Fundamentais, op. cit., p. 299 e ss . (2 ${ }^{\mathrm{a}}$ parte, 3.4.4.).

${ }^{50}$ Cf. RESpn. 668216

${ }^{51}$ Cf. BVerfG, 1 BvR 347/98, de 6.12.2005, disponível em http://www.bverfg.de/entscheidungen/rs20051206
} 
mecanismos de controle social ${ }^{52}$. Quanto mais efetivo for o acesso pela via administrativa, menos trilhado - por desnecessário - tenderá a ser o caminho judicial. Da mesma forma, como já proposto por alguns, há que aperfeiçoar tanto as possibilidades de acesso ao caminho jurisdicional, para que também neste plano se alcance maior isonomia ${ }^{53}$, quanto investir na efetividade do processo judicial, pois resulta evidente que uma prestação jurisdicional morosa e ineficiente também constitui um obstáculo para a eficácia e efetividade dos direitos fundamentais, no caso, do direito à saúde.

Por outro lado, se é possível afirmar a correção do entendimento de que a tutela coletiva (especialmente em nível preventivo) deva assumir caráter preferencial, já que possui a incensurável virtude de minimizar uma série de efeitos colaterais mais problemáticos da tutela jurisdicional individual na esfera dos direitos a prestações sociais ${ }^{54}$, também é certo - de acordo com o que se extrai da decisão do STF já referida, que assegurou o fornecimento de medicamento de alto custo em demanda individual promovida pelo Ministério Público Federal ${ }^{55}$, - que a eliminação da possibilidade de demandas individuais poderá, por si só, representar uma violação de direitos fundamentais, notadamente quando em causa o direito a uma vida digna e quando não assegurado um patamar suficiente de proteção social. Não se pode olvidar - e importa repisar tal aspecto! - que a tutela individual poderá, em determinadas hipóteses, ser mesmo a maneira mais adequada e mesmo necessária de proteção e promoção do direito, já pelo simples fato de que especialmente no campo do direito à saúde existem necessidades que apenas no contexto do caso individual podem ser adequadamente aferidas e satisfeitas, inclusive no âmbito de determinado grupo de pessoas portadoras de uma determinada enfermidade.

\section{CONSIDERAÇÕES FINAIS}

Muito embora a complexidade do tema e a diversidade dos argumentos não tenha permitido um inventário completo e nem uma análise pormenorizada, é possível, à luz das premissas lançadas e sumariamente desenvolvidas, apostar no acerto da tese de que tanto os direitos sociais (como, de resto, os direitos fundamentais no seu conjunto) em geral, quanto o direito à saúde em particular, possuem uma dupla dimensão individual e coletiva, e, nesta medida, uma titularidade - no que diz com a condição de sujeito de direitos subjetivos - igualmente individual e transindividual,

\footnotetext{
${ }^{52}$ Neste sentido, pugnando também por uma gestão democrática do orçamento público, v., por todos, R. G. Leal, Estado, Administração Pública e Sociedade. Porto Alegre: Livraria do Advogado, 2006, especialmente

p. 57 e ss.
53 Cf., por exemplo, a sugestão de C. P. Souza Neto “A justiciabilidade dos direitos sociais: críticas e parâmetros”, in: C. P. Souza Neto e D. Sarmento (Coord.). Direitos Sociais, op. cit., p. 543 e ss.

${ }^{54}$ Em especial, as contribuições de L. R. Barroso "Da falta de efetividade à judicialização excessiva: direito à saúde, fornecimento gratuito de medicamentos e parâmetros para a atuação judicial”, in: Direitos Sociais, op. cit., p. 897 e ss.; A. P. Barcellos, "O direito a prestações de saúde: complexidades, mínimo existencial e o valor das abordagens coletiva e abstrata”, in: Direitos Sociais, op. cit., p. 815 e ss.; C. P. Souza Neto, "A justiciabilidade dos direitos sociais: críticas e parâmetros”, in: Direitos Sociais, op. cit., p. 543 e ss.; D. Sarmento “A proteção judicial dos direitos sociais: alguns parâmetros ético-jurídicos”, in: Direitos Sociais. op. cit., p. 583 e ss.

${ }^{55}$ Cuida-se da já citada STA 175, de 18.09.2009, Rel. Min. Gilmar Mendes.
} 
tal como acertadamente vem sendo reconhecido pelo próprio STF. Cuida-se, portanto, de direitos de todos e de cada $\mathrm{um}^{56}$, de tal sorte que o desafio é saber harmonizar, sem que ocorra a supressão de uma das dimensões, ambas as perspectivas.

Da mesma forma, se as objeções em relação à tutela judicial individual não podem ter o condão de afastar tal via de efetivação dos direitos sociais (cujo sujeito, ainda mais no caso do direito à saúde, segue sendo, em primeira linha, o indivíduo concreto, com sua dignidade) também é certo que é preciso empreender ajustes e minimizar os efeitos negativos da litigância individual, seja mediante um controle mais rigoroso no que diz com a necessidade da prestação pleiteada, seja no respeitante a outros aspectos, parte dos quais referidos como possibilidades aptas a propiciar uma maior racionalidade e eficácia no plano das estratégias de efetivação dos direitos sociais em geral e do direito à saúde em particular. A preferência (mas não exclusividade) da tutela coletiva e preventiva há de vir acompanhada do aperfeiçoamento dos processos administrativos, do controle social, da ampliação e isonomia no campo do acesso à justiça, sem prejuízo de outras medidas (como a participação efetiva na definição do orçamento público e sua execução, inclusive com maior atuação do Ministério Público nessa seara) que, no seu conjunto, poderão assegurar maior eqüidade ao sistema, o que certamente não passa pela supressão da possibilidade da tutela individual e do exame cuidadoso das violações e ameaças de violação da dignidade de cada pessoa humana. Além do mais, como já tivemos oportunidade de destacar em outra oportunidade, não há como desconsiderar que o direito de cada indivíduo (individual ou coletivamente) buscar no âmbito do Poder Judiciário a correção de uma injustiça e a garantia de um direito fundamental, acaba, numa perspectiva mais ampla, por reforçar a esfera pública, pois o direito de ação assume a condição de direito de cidadania ativa e instrumento de participação do indivíduo no controle dos atos do poder público.

\section{REFERÊNCIAS BIBLIOGRÁFICAS}

AGRA, Walber de Moura. Curso de Direito Constitucional. Rio de Janeiro: Forense, 2006.

ALEXANDRINO, Marcelo. Direitos Fundamentais. Introdução Geral, Estoril: Principia Editora, 2007.

AMARAL, Gustavo. Direito, Escasssez \& Escolha. 2. ed., Rio de Janeiro: Lumen Juris, 2010.

ARANGO, Rodolfo. El Concepto de Derechos Sociales Fundamentales, Bogotá: LEGIS, 2005.

BARCELLOS, Ana Paula de. A Eficácia Jurídica dos Princípios Constitucionais. O Princípio da Dignidade da Pessoa Humana. Rio de Janeiro: Renovar, 2002.

"O direito a prestações de saúde: complexidades, mínimo existencial e o valor das abordagens coletiva e abstrata”, in: SOUZA NETO, Cláudio Pereira; SARMENTO, Daniel. Direitos Sociais. Fundamentos, Judicialização e Direitos Sociais em Espécie. Rio de Janeiro: Lumen Juris, 2008.

${ }^{56}$ Aqui se utilizou a fórmula de V. Rigo, "Saúde: direito de todos e de cada um”, in: A. de Assis (Org), Aspectos Polêmicos e Atuais dos Limites da Jurisdição e do Direito à Saúde, Porto Alegre: Notadez, 2007, p. 173 e ss. 
BARROSO, Luis Roberto. "Da falta de Efetividade à Judicialização Excessiva: Direito à Saúde, Fornecimento Gratuito de Medicamentos e Parâmetros para a Atuação Judicial”, in: SOUZA NETO, Cláudio Pereira; SARMENTO, Daniel. Direitos Sociais. Fundamentos, Judicialização e Direitos Sociais em Espécie. Rio de Janeiro: Lumen Juris, 2008.

BESTER, Gisele Maria. Direito Constitucional. Vol. I: Fundamentos Teóricos. Manole: Barueri, 2005.

BONAVIDES, Paulo. Curso de Direito Constitucional. 7. ed. São Paulo: Malheiros, 1998.

CALIENDO, Paulo. Direito Tributário e Análise Econômica do Direito. Uma Visão Crítica. São Paulo: Elsevier, 2008.

CANOTILHO, José Joaquim Gomes. Direito Constitucional e Teoria da Constituição. 7. ed. Coimbra: Almedina, 2003.

CASTRO, Carlos Roberto Siqueira. A Constituição Aberta e os Direitos Fundamentais ensaios sobre um constitucionalismo pós-moderno e comunitário. Rio de Janeiro: Forense: 2005.

DIMOULIS, Dimitri; MARTINS, Leonardo. Teoria Geral dos Direitos Fundamentais. São Paulo: RT, 2007.

FIGUEIREDO, Mariana Filchtiner. Direito Fundamental à Saúde. Parâmetros para sua eficácia e efetividade, Porto Alegre: Livraria do Advogado, 2007.

"Apontamentos acerca do objeto do direito à saúde: para além do dever de prestação de medicamentos e tratamentos", trabalho apresentado como requisito de conclusão de disciplina no Doutorado em Direito da PUCRS, Porto Alegre: dez. 2009.

HÄBERLE, Peter. “Grundrechte im Leistungsstaat”, in: VVDStrL n. 30, 1972.

JUAN, Stéphanie. "L’objectif à valeur constitutionnelle du droit à la protection de la santé: droit individuel ou collectif?”, in: Revue du Droit Public et de la Science Politique en France et à L'ètranger $\mathrm{n}^{\circ} 2,2006$.

LEAL, Rogério Gesta. Condições e Possibilidades Eficaciais dos Direitos Fundamentais Sociais. Porto Alegre: Livraria do Advogado, 2009.

Estado, Administração Pública e Sociedade. Porto Alegre: Livraria do Advogado, 2006.

LEDUR, José Felipe. Direitos Fundamentais Sociais. Efetivação no Âmbito da Democracia Participativa. Porto Alegre: Livraria do Advogado, 2009.

LOPES, José Reinaldo de Lima. Direitos Sociais. Teoria e Prática. São Paulo: Método, 2006.

LUÑO, Antonio Enrique Pérez. "La positividad de los derechos sociales en el marco constitucional”, in: Uma homenagem aos 20 anos da Constituição Brasileira, Florianópolis: Fundação Boiteux, 2008.

MARMELSTEIN, George. Curso de Direitos Fundamentais. São Paulo: Atlas Jurídico, 2008.

MENDES, Gilmar Ferreira. "Direito de Nacionalidade e Regime Jurídico do Estrangeiro”, in: Direitos Fundamentais \& Justiça, Revista do Programa de Pós-Graduação Mestrado e Doutorado da PUCRS, Porto Alegre: Ano 1, nº 1, out./dez. 2007.

; COELHO, Inocêncio Mártires; BRANCO, Paulo Gustavo Gonet. Curso de Direito Constitucional. 2. ed. São Paulo: Saraiva, 2008.

MIRANDA, Jorge. Os Direitos Fundamentais - Sua Dimensão Individual e Social, in: CDCCP n ${ }^{\circ} 1(1992)$.

; MEDEIROS, Rui. Constituição Portuguesa Anotada. Tomo I. Coimbra: Coimbra Editora, 2005.

DIREITOS FUNDAMENTAIS E JUSTIÇA N' 10 - JAN./MAR. 2010 
MORAES, Alexandre de. Direitos Humanos Fundamentais - Teoria Geral, 6. ed. São Paulo: Atlas, 2005.

MORAIS, José Luís Bolzan de. Do Direito Social aos Interesses Transindividuais. O Estado e o Direito da Ordem Contemporânea. Porto Alegre: Livraria do Advogado Editora, 1996.

MÜNCH, Ingo von. Grundgesetz-Kommentar, vol. I, 5. ed., München: C.H, Beck, 2000.

NETO, Eurico Bitencourt. O Direito ao Mínimo para uma Existência Digna. Porto Alegre: Livraria do Advogado, 2010.

NUNES, Anelise Coelho. A Titularidade dos Direitos Fundamentais na Constituição Federal de 1988. Porto Alegre: Livraria do Advogado, 2007.

PISARELLO, Gerardo. Los derechos sociales y sus garantías. Madrid: Trotta, 2007.

RIGO, Vivian. "Saúde: direito de todos e de cada um”, in: A. de Assis (Org.), Aspectos Polêmicos e Atuais dos Limites da Jurisdição e do Direito à Saúde. Porto Alegre: Notadez, 2007.

SARLET, Ingo Wolfgang. A Eficácia dos Direitos Fundamentais. Uma teoria geral dos direitos fundamentais na perspectiva constitucional. 10. ed. Porto Alegre: Livraria do Advogado, 2009.

. Dignidade da Pessoa Humana e Direitos Fundamentais na Constituição Federal de 1988. 7. ed. Porto Alegre: Livraria do Advogado, 2009.

. "Os Direitos Fundamentais Sociais na Constituição de 1988”, in: SARLET, Ingo Wolfgang. (Org.). Direito Público em Tempos de Crise. Porto Alegre: Livraria do Advogado, 1999.

SARMENTO, Daniel. “A proteção judicial dos direitos sociais: alguns parâmetros ético-jurídicos”, in: SOUZA NETO, Cláudio Pereira; SARMENTO, Daniel. Direitos Sociais. Fundamentos, Judicialização e Direitos Sociais em Espécie. Rio de Janeiro: Lumen Juris, 2008.

SILVA, José Afonso da. Curso de Direito Constitucional Positivo, 27. ed. São Paulo: Malheiros, 2006.

SILVA, Virgílio Afonso da. "O Judiciário e as políticas públicas: entre transformação social e obstáculo à realização dos direitos sociais”, in: SOUZA NETO, Cláudio Pereira; SARMENTO, Daniel. Direitos Sociais. Fundamentos, Judicialização e Direitos Sociais em Espécie. Rio de Janeiro: Lumen Juris, 2008.

SOUZA NETO, Cláudio Pereira. “A Justiciabilidade dos Direitos Sociais: Críticas e Parâmetros”, in: SOUZA NETO, Cláudio Pereira; SARMENTO, Daniel. Direitos Sociais. Fundamentos, Judicialização e Direitos Sociais em Espécie. Rio de Janeiro: Lumen Juris, 2008.

TIMM, Luciano Benetti.”Qual a maneira mais eficiente de prover direitos fundamentais: uma perspectiva de Direito e Economia", in: SARLET, Ingo Wolfgang; TIMM, Luciano Benetti (Orgs.). Direitos Fundamentais, Orçamento e Reserva do Possível. Porto Alegre: Livraria do Advogado, 2008.

TORRES, Ricardo Lobo. O Direito ao Mínimo Existencial. Rio de Janeiro: Renovar, 2008.

WOLKMER, Antônio Carlos. "Direitos Políticos, Cidadania e Teoria das Necessidades", in: Revista de Informação Legislativa ${ }^{\circ} 122$ (1994).

ZAVASCKI, Teori Albino. Processo Coletivo. Tutela de Direitos Coletivos e Tutela Coletiva de Direitos, 4. ed., São Paulo: Editora Revista dos Tribunais, 2009. 